\title{
Effects of spatial aggregation on predictions of forest climate change response
}

\author{
M artha K. N ungesser ${ }^{1}$, Linda A. J oyce ${ }^{2, *}$, A. David M cG uire ${ }^{3}$ \\ ${ }^{1}$ M ACA, Fort Collins, Colorado 80526, USA \\ ${ }^{2}$ Rocky M ountain Research Station, 240 West Prospect, Fort Collins, C olorado 80526, USA \\ ${ }^{3}$ A laska Cooperative Fish and Wildlife Unit, University of Alaska, Fairbanks, Alaska 99775-7020, USA
}

\begin{abstract}
We investigated the influence of spatial aggregation on modeled forest responses to climate change by applying the process-based Terrestrial Ecosystem M odel (TEM) to a fine resolution spatial grid $\left(100 \mathrm{~km}^{2}\right)$ and to a coarse resolution spatial grid $\left(2500 \mathrm{~km}^{2}\right)$. Three climate scenarios were simulated: baseline (present) climate with ambient $\mathrm{CO}_{2}$ and 2 future climates derived from the general circulation models OSU and GFDL-Q with elevated atmospheric $\mathrm{CO}_{2}$. For baseline climate, the aggregation error of the national (U.S.) study area was very small, $-0.4 \%$. Forest-level aggregation error ranged from -1.6 to $11.8 \%$, with the largest aggregation error occurring in boreal forest types. Coarse grid resolution inputs underestimated production for boreal and forested boreal wetland forests and overestimated net primary production (NPP) for temperate conifer, temperate deciduous, and temperate forested wetland forests. Aggregation error for coarse grid cells ranged between -25.6 and $27.3 \%$. Aggregation errors were especially large in transition regions between temperate and boreal forest types. An analysis that homogenized inputs for the $10 \mathrm{~km}$ grid cells within a $50 \mathrm{~km}$ grid indicated that aggregation of forest types and air temperature from fine to coarse grid cells contributed most to the spatial aggregation error. The aggregation error for the OSU climate was similar to the GFDL-Q climate and both results were similar to the aggregation error of the baseline climate in magnitude, sign, and spatial pattern. While aggregation error was similar across the baseline, GFDL-Q and OSU scenarios, NPP response to the GFDL-Q and OSU climates increased 13 to $30 \%$ above the baseline NPP. Within each climate scenario, the estimated NPP response to climate change differed by less than $1 \%$ between the coarse and fine resolutions. Except for transition regions and regions with substantial variability in air temperature, our simulations indicate that the use of $0.5^{\circ}$ resolution provides an acceptable level of aggregation error at the 3 scales of analysis in this study. Improvements could be made by focusing computational intensity in heterogeneous regions and avoid computational intensity in regions that are relatively homogeneous with respect to vegetation and air temperature.
\end{abstract}

KEY WORDS: Terrestrial Ecosystem Model · Integrated assessments - Net primary production . Scaling · Vegetation · Temperature

\section{INTRODUCTION}

Assessments of the impact of climate change have identified the importance of integrating the ecological and the economic and social analyses at large spatial scales (Houghton et al. 1996, Watson et al. 1996). Global climate change scenarios, derived from climate models, have been used in biome redistribution models and in process-based ecosystem models to evaluate the potential consequences of climate change in ter-

*Addressee for correspondence.

E-mail: ljoyce/rmrs@fs.fed.us restrial ecosystems at large spatial scales, e.g. in continental-level analyses (Melillo et al. 1993, 1996, VEM AP M embers 1995). Similarly, the results of these ecological models have been used to analyze the impacts of climate change on the supply and demand of timber at country and global scales (J oyce 1995, Perez-Garcia et al. 1997, Sohngren et al. 1998), and the impacts on regional economies at the global scale (Xiao et al. 1997). The nature of these assessments, country-level and inter-governmental, requires large spatial extent. Computational limitations result in a tradeoff between the spatial extent and the grain or cell size in the analysis. 
Climate, vegetation, topography and soil input data for these ecological models are typically gridded at the $0.5^{\circ}$ longitude by $0.5^{\circ}$ latitude scale (VEM AP M embers 1995, Woodward et al. 1995, Cramer et al. 1999). The coarseness of this grid size reflects past availability of data, areal extent of the studies, and computational limitations for these models. Use of gridded input data implicitly assumes that the mean or dominant surface features represent the entire grid cell. Inherent in this assumption is the uncertainty with which each gridded value represents the heterogeneity of the actual climate processes and the surface features within the gridded area and the representativeness of this gridded value when used by ecological models to describe the biological processes operating within the gridded area. The utility of various aggregation schemes in summarizing fine resolution data has been reviewed for different physical and biological attributes elsewhere (Turner et al. 1989a,b, Kittel et al. 1996).

The degree to which methods of aggregation and grid resolution affect the results and conclusions drawn from these ecological simulations has been studied in a few limited situations. The proportional aggregation scheme assigns cell values to the coarser grain grid cell according to the dominant category found within the resampling matrix of the fine grain cells (Costanza \& Maxwell 1994). While this scheme eliminates rare types, Costanza \& Maxwell (1994) found little difference for their modeling objectives between this scheme and a random aggregation scheme. In contrast, concerns about physical consistency led Kittel et al. (1996) to use the dominant soil profiles and their frequency distribution rather than averages in the development of soil data for $0.5^{\circ}$ grid size. The nonlinear relationship between the physical aspects of soil and the soil processes such as water balance would be poorly characterized if the average soil properties were used. Net primary production (NPP) estimates from the PnEt model differed by $20 \%$ when coarse grain versus fine grain soil data were used as input data (Lathrop et al. 1995). Using the FOREST-BGC model, Pierce \& Running (1995) examined the bias in NPP model estimates resulting from averaging of subgrid variations in climate, topography, soils and vegetation across a series of grain sizes from $1 \mathrm{~km}$ to $1^{\circ}$. They obtained overestimates of up to $30 \%$ in NPP from coarse resolution grids relative to the $1 \mathrm{~km}^{2}$ fine resolution grids used to characterize coniferous forests in the Rocky M ountains. M ost of this error was produced by average temperature, while average topography, soils, and vegetation types also contributed. None of these studies has examined the effect of aggregation on predicted ecosystem responses to climate change.

Opportunities to move these assessment analyses to finer resolution, such as $10 \mathrm{~km}$, exist. It is important to understand the utility of going to a finer scale. Moving from $0.5^{\circ}$ to $10 \mathrm{~km}$ grid size represents an order of magnitude greater effort in terms of data size and model running time. Costanza \& Maxwell (1994) posited that there is a different optimal resolution for each class of models and possibly for each particular set of modeling objectives. We used the Terrestrial Ecosystem Model (TEM) (M elillo et al. 1993) to evaluate the utility of moving the climate change impact analysis to a finer resolution. We simulated forest ecosystem responses to a baseline climate and to 2 climate change scenarios at 2 different spatial resolutions. Spatial aggregation error, as we define it, represents the difference between 2 NPP estimates made at the coarse and at the fine resolution relative to the estimate at fine resolution. We hypothesized that aggregation error would increase in the climate change scenarios relative to that of baseline climate.

\section{METHODS}

Our approach to comparing effects of aggregation was to simulate forest NPP for baseline and 2 climate change scenarios at 2 resolutions within the same spatial extent. Aggregation error was computed at the coarse resolution with the finer resolution NPP serving as the control. The fine resolution (sensu Turner et al. 1989b) grid cells were $100 \mathrm{~km}^{2}$ in size, nested within coarse resolution grid cells of approximately a half degree in size $\left(2500 \mathrm{~km}^{2}\right)$.

We quantified the impact of aggregation in 3 simulation experiments. First, we computed aggregation error using the historical climate under which the ecological processes have been studied, and for which the ecological models have been validated, the baseline climate. Second, we examined the contribution to aggregation error of the variability of each climate input in isolation of other inputs. Third, we assessed aggregation error under the climate change scenarios and compared it to the aggregation error for the baseline simulations. Because climate change assessments vary in their scale of analysis, we summarized our results at 3 spatial scales: grid cell, forest type, and national. The national scale encompassed the historical range of temperate forests in the United States, the spatial extent of this analysis.

We used TEM (version 4.0, McGuire et al. 1995), a process-based ecosystem model that uses spatially distributed input data for climate (monthly temperatures, precipitation, and cloudiness), soils (percent sand, silt, and clay), and vegetation (35 vegetation classes globally) (Fig. 1). TEM reports equilibrium estimates of carbon and nitrogen fluxes and pools, including NPP in $\mathrm{g} \mathrm{C} \mathrm{m}^{-2} \mathrm{yr}^{-1}$ (M cGuire et al. 1995, 1997, Pan et al. 1996). 


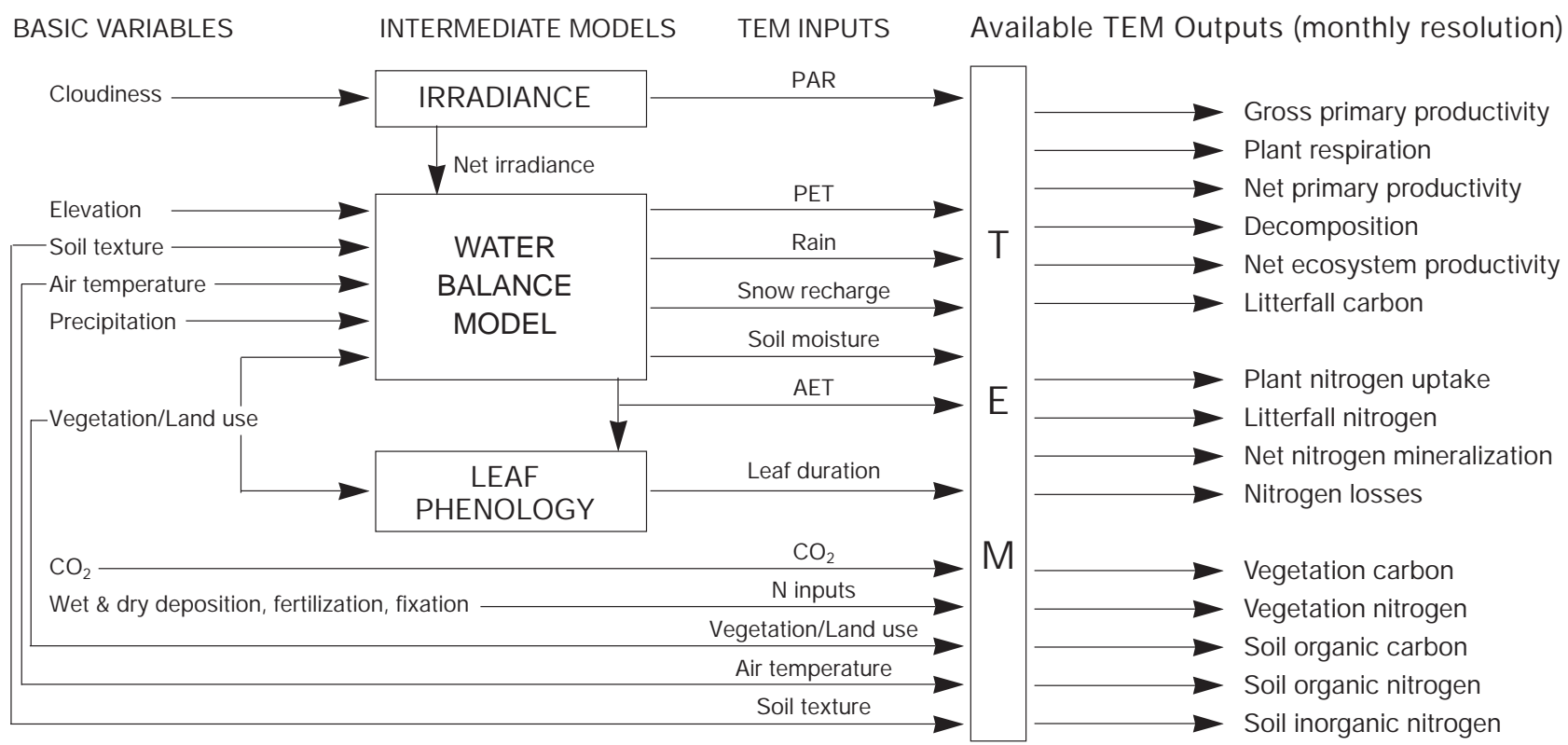

Fig. 1. Inputs and outputs of the Terrestrial Ecosystem M odel (TEM) (from Pan et al. 1996). PAR: photosynthically active radiation; PET: potential evapotranspiration; AET: actual evapotranspiration; $\mathrm{CO}_{2}$ : atmospheric $\mathrm{CO}_{2}$ concentration

TEM was developed and has been used extensively to simulate processes at large spatial scales using generalized biological and physical processes for ecosystems. Its customary applications have been to estimate global and continental ecosystem NPP, soil carbon under contemporary and alternate climates and varying levels of $\mathrm{CO}_{2}$, and interactions between nitrogen and carbon in terrestrial ecosystems.

2.1. Aggregation of spatial input data. Within the historical range of temperate forests within the conterminous United States (J oyce 1995), we selected only coarse resolution grid cells whose component fine cells were all classified as forested. This selection criterion ensured the same spatial extent at both the coarse and fine resolutions. When any of the 25 fine resolution cells were water or a nonforest type, such as grasslands, shrublands, desert, or wetlands, the entire coarse resolution grid was eliminated from this analysis. While this decision rule eliminated most of the Rocky M ountain region and prai rie riparian zones from consideration, it included most of the eastern and forested western mountainous regions. The forest types represented in the resulting 815 coarse resolution grid cells are boreal, forested boreal wetland, temperate conifer, temperate deciduous, mixed temperate, and temperate forested wetlands (Fig. 2).

The $10 \mathrm{~km} \times 10 \mathrm{~km}$ baseline input data for climate (monthly preci pitation, monthly mean air temperature), soil texture (percent sand, silt, and clay), and elevation were obtained from $\mathrm{N}$ eilson (pers. comm.) as described for climate in Marks (1990), Neilson (1995), Daly et al.
(1994), and for soils in Kern (1994). The temperature and precipitation data represent long-term monthly means (Leemans \& Cramer 1991). Küchler vegetation was digitized from the 1975 map (Küchler 1975) at $10 \mathrm{~km}$ resolution (Steve Hodge pers. comm.) and was reclassified to TEM vegetation types (Table 6 in VEMAP Members 1995). The source data for soils (Kern 1994) and cloudiness (Hahn et al. 1988) were coarsely resolved and for these inputs we did not examine aggregation error. In TEM, elevation is used explicitly only to determine the duration of snowmelt (Vorosmarty et al. 1989). Elevation was used to correct the input air temperature and precipitation data for adiabatic lapse rates (Marks 1990). Therefore, we did not examine aggregation error separately for elevation as it was confounded with temperature and precipitation.

The $50 \mathrm{~km} \times 50 \mathrm{~km}$ baseline input data was created by aggregation of the fine resolution input data. Each coarse resolution cell contained 25 of the $10 \mathrm{~km} \times$ $10 \mathrm{~km}$ grid cells. The continuous values of climate, soils, and elevation were averaged to obtain the mean of the 25 fine resolution grids. The proportional aggregation method (Costanza \& M axwell 1994) was used to identify forest type at the coarse grid resolution. In this method, the majority type of the 25 categorical values of forest type at the fine resolution was selected as the forest type of the coarse grid cell.

The decision rule of proportional aggregation results in some loss of information on the areal extent of forests (Table 1 ). While the coarse resolution grids include 6 vegetation types, a seventh type, temperate 

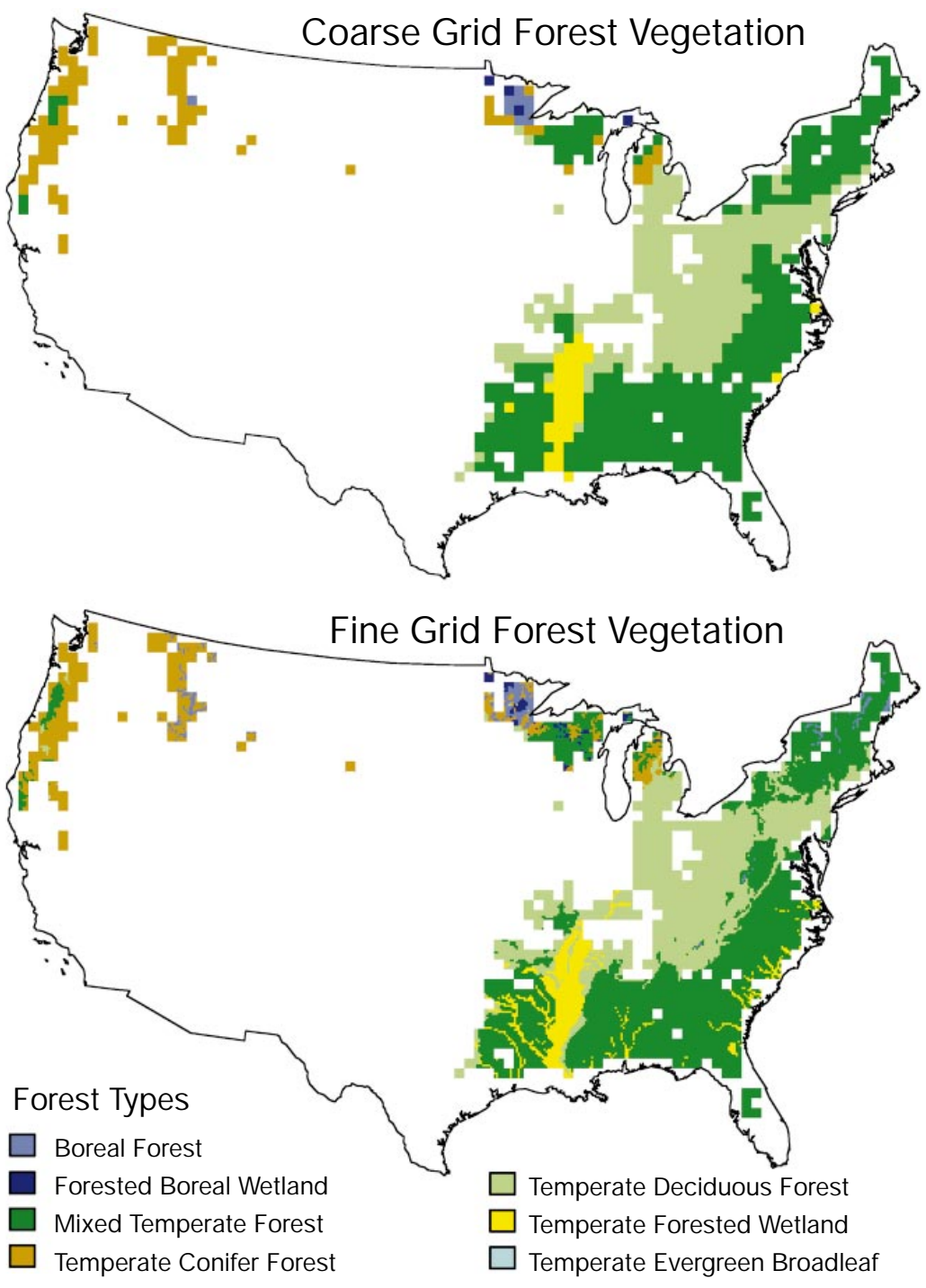

Fig. 2. Forest types at coarse $(50 \mathrm{~km})$ and fine $(10 \mathrm{~km})$ resolution grids for our study area. Coarse resolution grid cells were included when all 25 fine resolution grids within their boundaries were classified as forest vegetation comm.) as described in Neilson \& M arks (1994) are based on 2 general circulation models (GCMs): the Geophysical Fluid Dynamics Laboratory Q-flux (GFDL-Q) (M anabe \& Wetherald 1987) and Oregon State University (OSU) (Schlesinger \& Zhao 1989) models. The scenarios were interpolated from the climate models coarse grids to the $10 \mathrm{~km}$ grid size and then applied to the $10 \mathrm{~km}$ version of the long-term climate data set of Leemans \& Cramer (1991) (Neilson \& Marks 1994). The $10 \mathrm{~km}$ grid cell values for forest type, elevation, and soils remain unchanged from the baseline simulation. Using the same aggregation protocol as for baseline climate, the climate change scenarios at the $10 \mathrm{~km}$ grid size were aggregated within the $50 \mathrm{~km}$ grid cells to serve as coarse resolution inputs to TEM for the climate change scenarios.

2.2. Simulation experiments. We investigated aggregation error with 3 simulation experiments. First, we assessed aggregation error under baseline climate. Second, we determined the effects that each fine resolution input had on aggregation error for baseline values. Third, we determined aggregation error for the 2 climate change scenarios and compared this error to that under baseline climate. These tests determined whether and how much aggregation error changed relative to baseline.

The first experiment computed the effect of aggregation under conditions for which the ecological model was calibrated, an experiment similar to that evergreen broadleaf, appeared only at the fine resolution. All forest types which comprised greater than $10 \%$ of the total area within the $10 \mathrm{~km}$ grids retained at least $93 \%$ of their total area when aggregated to $50 \mathrm{~km}$ grid size. The rarer forest types, boreal, forested boreal wetland, temperate forest wetland, and temperate broadleaf evergreen lost from 28 to $100 \%$ of their area under the proportional aggregation rule.

The climate change scenarios (monthly mean air temperature, monthly precipitation) obtained from $\mathrm{N}$ eilson (pers.
Table 1. Total forest type area $\left(\mathrm{km}^{2}\right)$ as influenced by the proportional aggregation scheme used to aggregate forest type from the $10 \mathrm{~km}$ (fine) resolution to the $50 \mathrm{~km}$ (coarse) resolution

\begin{tabular}{|c|c|c|c|c|}
\hline \multirow[t]{2}{*}{ Forest type } & \multicolumn{2}{|c|}{ Fine resolution } & \multicolumn{2}{|c|}{ Coarse resolution } \\
\hline & No. of cells & Is Area & No. of cells & S Area \\
\hline Boreal & 460 & 46000 & 9 & 22500 \\
\hline Forested boreal wetland & 154 & 15400 & 4 & 10000 \\
\hline Mixed temperate & 9621 & 962100 & 409 & 1022500 \\
\hline Temperate conifer & 2132 & 213200 & 91 & 227500 \\
\hline Temperate deciduous & 6555 & 655500 & 260 & 650000 \\
\hline Temperate forested wetland & 1450 & 145000 & 42 & 105000 \\
\hline Temperate evergreen broadleaf & 3 & 300 & 0 & 0 \\
\hline Total & 20375 & 2037500 & 815 & 2037500 \\
\hline
\end{tabular}


conducted by Pierce \& Running (1995). Model estimates of NPP were produced for the 20375 grid cells sized $10 \mathrm{~km} \times 10 \mathrm{~km}$ and for the 815 grid cells sized $50 \mathrm{~km} \times 50 \mathrm{~km}$ under baseline air temperature, precipitation, cloudiness, and $\mathrm{CO}_{2}$ levels of 355 meq I $^{-1}$.

Aggregation error measures the relative differences between fine and coarse resolution grid NPP. When averaging of input data adequately represents a grid cell, then the NPP estimates at the coarse resolution will be nearly identical to the fine resolution grid means. When it does not, NPP will differ or be skewed in distribution, revealed through variability and ranges of NPP. Aggregation error was computed at the $50 \mathrm{~km}$ resolution by averaging the fine resolution $(10 \mathrm{~km})$ NPP and comparing this to the NPP of the corresponding coarse resolution grid $(50 \mathrm{~km})$. The average fine resolution NPP was calculated as:

$$
\overline{\mathrm{NPP}}_{10}=\left(\sum_{\mathrm{i}=1}^{25} \mathrm{npp} \mathrm{i}\right) / 25
$$

where $\overline{\mathrm{NPP}}_{10}$ is the mean annual NPP in $\mathrm{g} \mathrm{C} \mathrm{m}^{-2} \mathrm{yr}^{-1}$ for the 25 fine resolution grids within each coarse resolution grid, $\mathrm{npp}_{\mathrm{i}}$ is the annual NPP for each fine resolution grid, and $i$ is the position of the 1st to 25th cells within the coarse resolution cell. Relative aggregation error for the baseline scenario $\left(\mathrm{E}_{\mathrm{B}}\right)$ was computed at the $50 \mathrm{~km}$ resolution from the difference between the control $\left(\overline{\mathrm{NPP}}_{10}\right)$ and NPP of the coarse resolution grid $\left(\mathrm{NPP}_{50}\right)$ as:

$$
E_{B}=100 \times \frac{\overline{N P P}_{10}-N P P_{50}}{\overline{N P P}_{10}}
$$

In the second experiment, we examined the role of each input variable in aggregation error by eliminating input variability one variable at a time. We ran TEM holding one input variable constant across all 25 fine resolution grids within each coarse grid while retaining variability among other input variables. For example, biological variability was eliminated at the fine resolution by assigning the majority forest type to all 25 cells contained within the coarse grid cell. TEM then produced NPP that reflected the influence of forest type on aggregation error through comparison with the original baseline fine resolution NPP and the coarse resolution NPP. TEM was run for the 3 homogenized inputs with fine resolution input data: forest type, air temperature, and precipitation. Mean NPP resulting from the homogeneous runs was calculated as:

$$
\overline{\mathrm{NPP}}_{\mathrm{h}}=\left(\sum_{\mathrm{i}=1}^{25} \mathrm{npp} \mathrm{p}_{\mathrm{hi}}\right) / 25
$$

where $\overline{\mathrm{NPP}}_{\mathrm{h}}$ is the mean NPP and $n p p_{h i}$ is NPP for the $i$ th grid cell. Two aggregation error measures were computed, $E h_{f}$ and $E h_{c}$ :

$$
\begin{aligned}
& E h_{f}=100 \times \frac{N P P_{10}-N P P_{h}}{N P P_{10}} \\
& E h_{c}=100 \times \frac{N P P_{50}-N P P_{h}}{N P P_{50}}
\end{aligned}
$$

where $E h_{f}$ and $E h_{c}$ are the aggregation errors associated with NPP where input data was homogenized and compared to the baseline NPP estimates for fine and coarse resolution, respectively.

The aggregation error $E h_{f}$ measures the relative difference between NPP estimated for each homogenized input run at the fine resolution and the baseline NPP at the fine resolution. In contrast, the aggregation error $E h_{c}$ measures the difference between NPP estimated for each homogenized input run at the coarse resolution and the baseline NPP estimate at the coarse resolution. If the input variable contributes to aggregation error, then homogenizing this input value will produce a NPP estimate that differs from the fine resolution NPP $\left(E h_{f}\right.$ and $E_{B}$ will differ) and more closely resembles the coarse resolution NPP $\left(E h_{C}\right.$ and $E_{B}$ will be similar).

The third simulation experiment computed aggregation error in NPP for the 2 climate change scenarios. The climate change scenarios represented altered temperature, precipitation, and cloudiness with a $\mathrm{CO}_{2}$ concentration of $625 \mathrm{ppmv}$ and were used in TEM to produce new NPP values. Although the GCMs, GFDL-Q and OSU, were implemented with slightly different atmospheric $\mathrm{CO}_{2}$ concentration, we elected to run TEM with a $\mathrm{CO}_{2}$ concentration of $625 \mathrm{ppmv}$ for both scenarios so that varying $\mathrm{CO}_{2}$ concentration would not be a factor in this aggregation analysis. The fine resolution grid means for climate change were calculated as:

$$
\begin{aligned}
& \overline{\mathrm{NPP}}_{\mathrm{OS} 10}=\left(\sum_{i=1}^{25} \mathrm{npp}_{\mathrm{OSi}}\right) / 25 \\
& \overline{\mathrm{NPP}}_{\mathrm{GQ} 10}=\left(\sum_{\mathrm{i}=1}^{25} \mathrm{npp}_{\mathrm{GQi}}\right) / 25
\end{aligned}
$$

where $\overline{\mathrm{NPP}}_{\mathrm{OS} 10}$ and $\overline{\mathrm{NPP}}_{\mathrm{GQ} 10}$ are the mean NPP of the fine resolution grids within a coarse resolution grid for each climate change scenario and $\mathrm{npp}_{\mathrm{OSi}}$ and $\mathrm{npp}_{\mathrm{GQ}}$ are the NPP values for each fine resolution grid. The NPP response to the climate change scenarios were calculated at the $50 \mathrm{~km}$ resolution as:

$$
\begin{aligned}
& d_{O S 10}=100 \times \frac{\overline{N P P}_{O S 10}-\overline{N P P}_{10}}{\overline{N P P}_{10}} \\
& d_{O S 50}=100 \times \frac{N P_{O S 50}-N P P_{50}}{N P P_{50}}
\end{aligned}
$$




$$
\begin{aligned}
d_{G Q 10} & =100 \times \frac{\overline{N P P}_{G Q 10}-\overline{N P P}_{10}}{\overline{N P P}_{10}} \\
d_{G Q 50} & =100 \times \frac{N P_{G_{Q 50}}-N P P_{50}}{N P P_{50}}
\end{aligned}
$$

where $\mathrm{d}_{\mathrm{OS} 10}, \mathrm{~d}_{\mathrm{OS50}}, \mathrm{d}_{\mathrm{GQ} 10}$, and $\mathrm{d}_{\mathrm{GQ} 50}$ were the NPP responses to the climate change scenarios for each fine and coarse resolution grids. Aggregation error within a scenario was computed for each $50 \mathrm{~km}$ grid as:

$$
\begin{aligned}
E_{O S} & =100 \times \frac{\overline{N P P}_{O S 10}-N P_{O S 50}}{\overline{N P P}_{O S 10}} \\
E_{G Q} & =100 \times \frac{\overline{N P P}_{G Q 10}-N P_{G Q 50}}{\overline{N P P}_{G Q 10}}
\end{aligned}
$$

where $E_{O S}$ is the aggregation error associated with the OSU climate scenario NPP results and $E_{G Q}$ is the aggregation errors associated with the GFDL climate scenario NPP results.

\section{RESULTS}

\subsection{Aggregation error for baseline climate}

For the national extent, the mean $50 \mathrm{~km} \mathrm{NPP}$ of all forests differed by less than $1 \mathrm{~g} \mathrm{C} \mathrm{m}^{-2}$ between fine and coarse resolution estimates (Table 2 ), a difference which was not significant (paired t-test: $\mathrm{p}=0.91, \mathrm{~N}=$ 815). Aggregation error based on 815 grid cells was very small and negative $(-0.4 \%)$, which reflects the slightly higher estimates of NPP using the coarse resolution input data. The range of aggregation error $(-25.6$ to $27.3 \%)$ reflects the differences at the level of each grid cell.

Among the forest types, mean $50 \mathrm{~km} \mathrm{NPP}$ of fine and coarse resolution estimates was most different for boreal forests $\left(37 \mathrm{~g} \mathrm{C} \mathrm{m}^{-2}\right.$ ) and forested boreal wetland $\left(34 \mathrm{~g} \mathrm{C} \mathrm{m}^{-2}\right)$. Although these differences were not sig- nificant (paired t-tests: $p=0.10$ and 0.12 ), the tests for differences were not powerful because of the low number of grid cells for the 2 types (see Table 2). For the other forest types, the difference between fine and coarse mean $50 \mathrm{~km} \mathrm{NPP}$ was less than $10 \mathrm{~g} \mathrm{C} \mathrm{m}^{-2}$. Of the other forest types, the difference in NPP approached significance only for deciduous forest (paired t-test: $p=0.08, N=260$ ). Similar to differences in mean $50 \mathrm{~km}$ NPP, the aggregation errors among forest types, which were larger than for all forests (Table 2), were largest in boreal forest $(11.8 \pm 6.9 \%)$ and forested boreal wetland $(9.6 \pm 12.2 \%)$. In contrast, for the other forest types the differences in mean absolute value of aggregation error was small (less than 2\%). For boreal forests, forested boreal wetland forests, and mixed temperate forests, the aggregation error was positive, whereas for conifers, deciduous, and temperate forested wetland types, the mean aggregation error was negative. Positive aggregation error indicated that the fine resolution grid NPP was larger than coarse resolution grid NPP. In boreal and forested boreal wetland forests, the aggregation error was positive for every grid cell as seen in the exclusively positive ranges in the aggregation error ( 3.7 to 22.1 and 0.1 to 27.3). Aggregation errors for the other forest types had ranges with both negative and positive values.

At the level of the individual grid cells, few cells had aggregation errors greater than $20 \%$ (Fig. 3), which is the approximate lower limit on measurement error of stand-level NPP. The largest aggregation errors occurred in grid cells around the Great Lakes, in northern New England, and in the Rocky Mountains. The smallest aggregation error was found generally throughout the East and Southeast, as well as in the western mountains. Each forest type, except temperate forested wetland, had at least 1 grid cell with an aggregation error exceeding $20 \%$, with the largest positive aggregation error of $27.3 \%$ for forested boreal wetlands and the largest negative error of $-25.6 \%$ for mixed temperate forests (Table 2).

Table 2. Net primary production (NPP) and aggregation error for baseline climate. Values are g C $\mathrm{m}^{-2}$ for NPP (NPP 50 and NPP 10 ,

\begin{tabular}{|c|c|c|c|c|c|c|}
\hline \multirow{3}{*}{$\begin{array}{l}\text { Forest type } \\
\text { Boreal }\end{array}$} & \multirow{3}{*}{$\begin{array}{l}\mathrm{n} \\
9\end{array}$} & \multicolumn{2}{|c|}{ NPP } & \multirow{3}{*}{$\begin{array}{c}\text { Paired t-test } \\
\text { significance } \\
0.10\end{array}$} & \multicolumn{2}{|c|}{ Aggregation error } \\
\hline & & Fine & Coarse & & & \\
\hline & & 312.4 (48.8) & $275.2(42.6)$ & & $11.8(6.9)$ & 3.7 to 22.1 \\
\hline Forested boreal wetland & 4 & 319.0 (36.6) & $285.0(9.8)$ & 0.12 & $9.6(12.2)$ & 0.1 to 27.3 \\
\hline Mixed temperate & 409 & 696.1 (124.9) & $691.0(113.8)$ & 0.54 & $0.3(4.1)$ & -25.6 to 8.4 \\
\hline Conifers & 91 & 344.7 (96.3) & $349.4(97.9)$ & 0.74 & $-1.6(5.6)$ & -24.1 to 9.6 \\
\hline Deciduous & 260 & $751.5(66.3)$ & $761.3(60.7)$ & 0.08 & $-1.4(2.7)$ & -24.3 to 0.8 \\
\hline Temperate forested wetland & 42 & $838.5(61.0)$ & $846.6(62.0)$ & 0.55 & $-1.0(1.8)$ & -6.4 to 0.3 \\
\hline All forests & 815 & $675.8(167.9)$ & 676.7 (165.3) & 0.91 & $-0.4(4.3)$ & -25.6 to 27.3 \\
\hline
\end{tabular}
Eq. 1) and relative percentages for aggregation error $\left(E_{B}, E q .2\right)$. Values are means, with standard deviations in parentheses. $\mathrm{n}$ : number of coarse resolution grid cells in each forest type. Significance level is given for the paired t-test comparing NPP and $\overline{\mathrm{NPP}}_{10}$ 


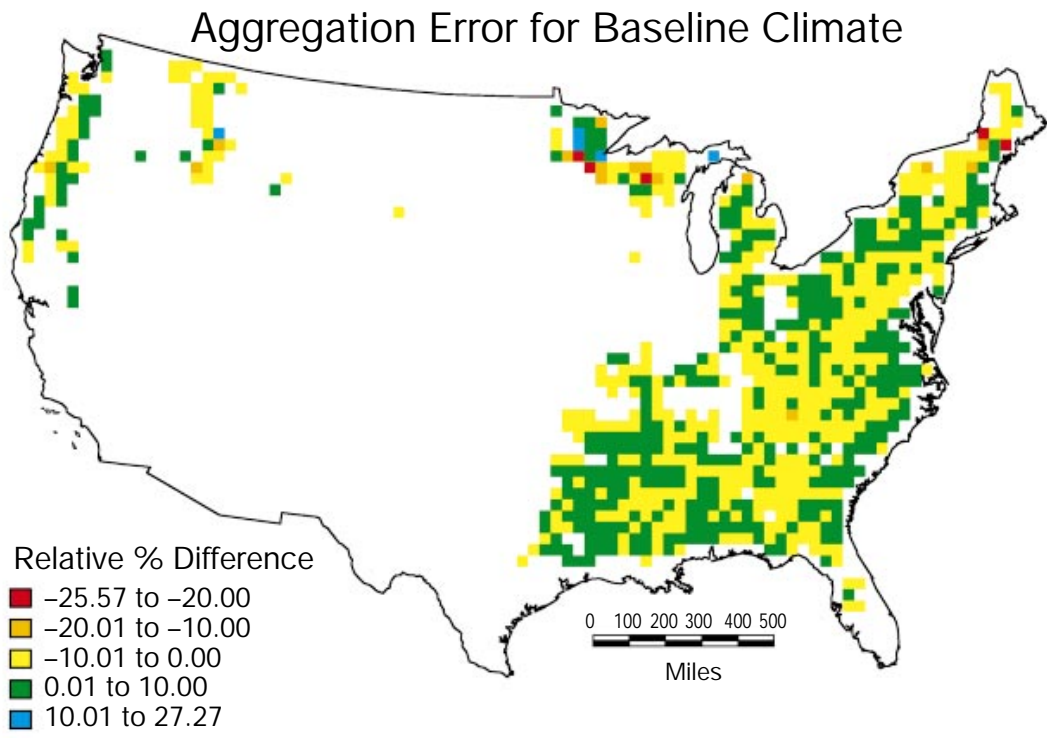

Fig. 3. Grid-level aggregation error for baseline climate, $E_{B}$ (Eq. 2)

gregation error. We computed aggregation error of the homogeneous inputs relative to both the baseline fine and coarse resolution grid NPP (Eqs. $4 \& 5$ ). When an input variable contributes little to aggregation error, then homogenizing the input produces an N PP estimate that differs little from the NPP of the baseline fine resolution grids. If the variable contributes to aggregation error, then homogenizing the input produces an N PP estimate that differs from the fine resolution NPP and more closely resembles the coarse resolution NPP.

When forest type is homogenized, the mean NPP results are close to both the baseline fine and coarse grid estimates of NPP, as indicated by aggregation errors $(-0.2$ and 0.1 respectively, Table 3) similar to the baseline -0.4 , Table 1). However, the ranges for $E h_{f}$

To determine whether increasing numbers of forest types within a coarse grid cell increased the magnitude of aggregation error, we plotted number of fine grid forest types against aggregation error within the coarse grid (Fig. 4). The largest aggregation errors for temperate conifer forest and deciduous forest were associated with grids containing the most forest types. However, this pattern was not repeated in the boreal and forested boreal wetland forests where the largest aggregation errors were found in grids with 2 or 3 different types, rather than the grid cells containing 4 forest types. In addition, aggregation error across grid cells with similar numbers of forest types spanned a wide range of values. Other factors, in addition to the number of forest types, appear to influence the magnitude of the aggregation error.

\subsection{Influences of input variables on aggregation error}

Aggregation error can stem from different forest types responding to the same environment, from a single forest type responding to different environments, or a combination of these responses. Eliminating fine resolution input variability one factor at a time has the potential to reveal the influence of each input factor on ag-

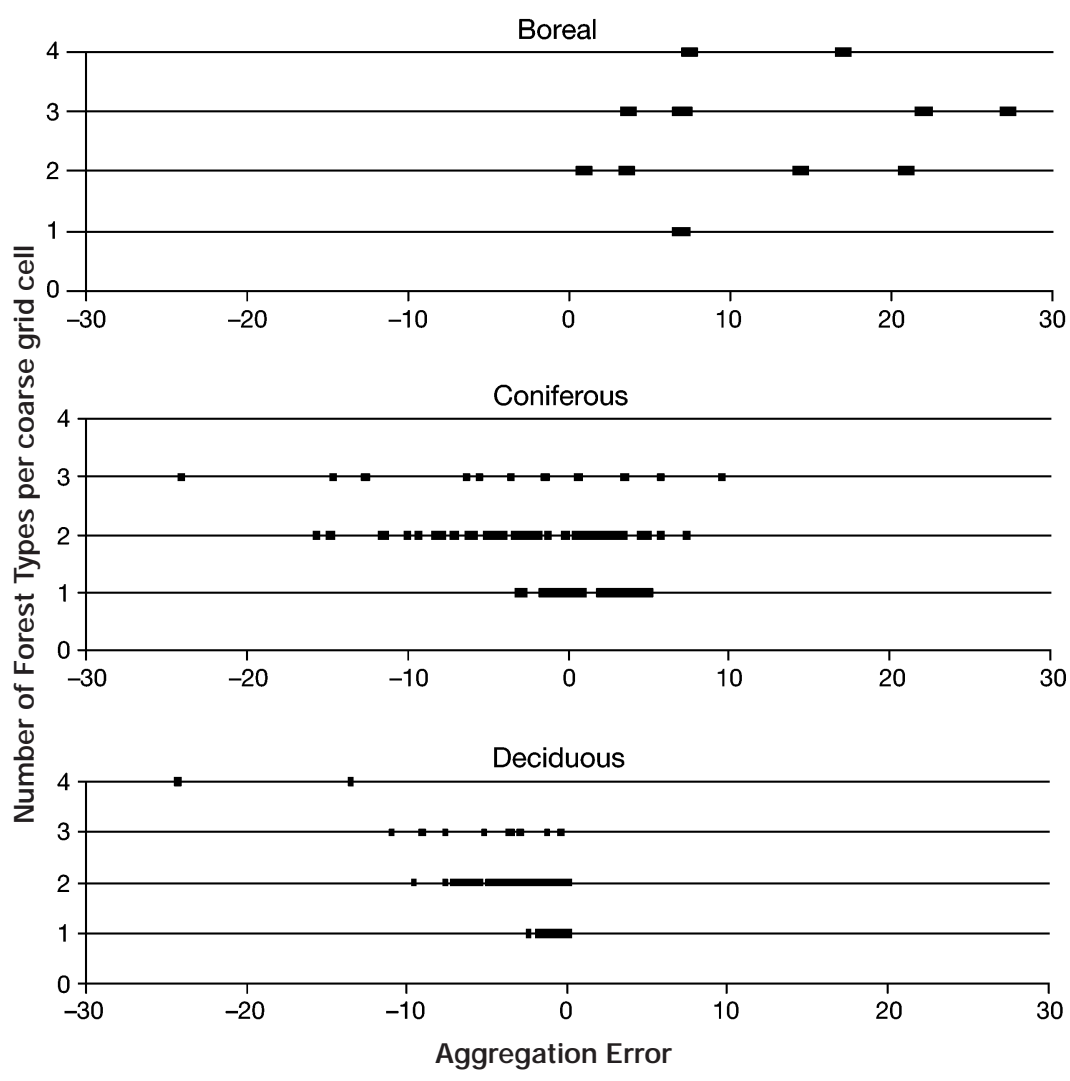

Fig. 4. Distribution of aggregation error for forest types relative to the numbers of different types at the fine resolution. Boreal includes both boreal forest and boreal forest wetland 
Table 3. Aggregation error for homogeneous fine resolution grids relative to baseline fine and coarse resolution NPP $\left(E h_{f}\right.$ and $E h_{c}$, Eqs. $\left.4 \& 5\right)$. These should be compared to the baseline aggregation error, $-0.4 \pm 4.3 \%$, with a range of -25.6 to $27.3 \%$. Values represent aggregation error mean, standard deviation, and range for the 815 forested grid cells in the study area

\begin{tabular}{|lcccc|}
\hline \multirow{2}{*}{ Input variable } & \multicolumn{2}{c}{$\mathrm{Eh}_{\mathrm{f}}$} & \multicolumn{2}{c|}{$\mathrm{Eh}_{\mathrm{c}}$} \\
& Mean (SD) & Range & Mean (SD) & \multicolumn{1}{c|}{ Range } \\
\hline Forest type & $-0.2(4.2)$ & -25.8 to 27.3 & $0.1(1.2)$ & -7.7 to 7.9 \\
Air temperature & $-1.4(2.6)$ & -6.9 to 15.1 & $1.6(5.1)$ & -33.8 to 22.8 \\
Precipitation & $-0.1(0.5)$ & -6.0 to 0.8 & $0.1(4.2)$ & -37.5 to 20.3 \\
\hline
\end{tabular}

These results imply that air temperature plays a larger role than forest type in aggregation error at the national resolution, but less so for individual grid cells. When precipitation is averaged, the mean fine and coarse resolution aggregation errors $(-0.1$ and $0.1 \%$ for $E h_{f}$ and $E h_{c}$, respectively) are less than baseline aggregation error (-0.4). The range of the fine resolution aggregation error for homogenized precipitation $(-6.0$ to $0.8 \%)$ is much smaller relative to coarse resolution aggregation error (-37.5 to $20.3 \%$ ) and baseline aggregation error (-25.6 to $27.3 \%$ ). These results indicate that precipitation plays a small role in determining aggregation error at the national extent and for individual grid cells.

The spatial patterns of aggregation error produced by homogenizing the input varied by input variable (Fig. 5). While baseline aggregation error represents the relative difference between fine and coarse resolution NPP estimates, the aggregation error in Fig. 5 represents the relative differences between the fine ture is also slightly larger than the baseline error.

\section{Fine Grid Differences Resulting From Homogenized Inputs}
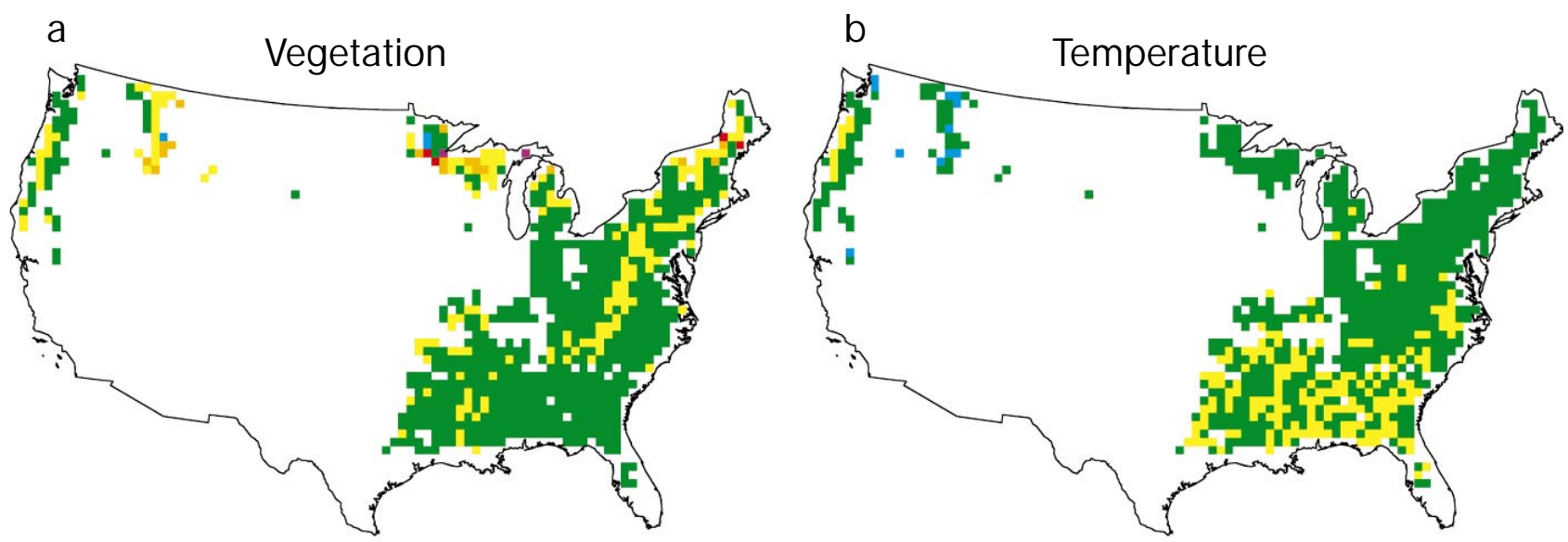

Relative \% Difference

$\begin{array}{ll}\square-26.00 \text { to }-20.00 & \square 0.01 \text { to } 10.00 \\ \square-20.01 \text { to }-10.00 & \square 10.01 \text { to } 20.00 \\ \square-10.01 \text { to } 0.00 & \square 20.01 \text { to } 28.00\end{array}$

Fig. 5. Relative differences between baseline fine resolution grids and grids with homogeneous (a) vegetation types, (b) air temperature regimes, and (c) precipitation $\left(\mathrm{E} \mathrm{h}_{\mathrm{f}}, \mathrm{Eq} .4\right)$

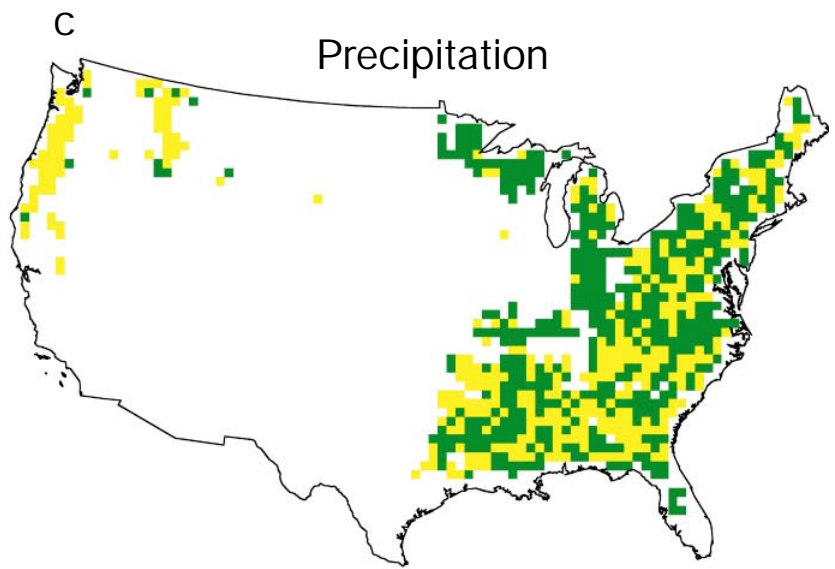


resolution and the homogenized fine resolution NPP estimates, $E h_{f}$ (Eq. 4). Negative aggregation error indicates that the fine resolution NPP values are less than the homogeneous values. Homogenizing forest type produced patterns (Fig. 5a) that reflect the transition between forest types (Fig. 2) rather than the overall spatial patterns of the baseline aggregation error, $E_{B}$ (Fig. 3). In the East, negative aggregation error is more concentrated in the Appalachians and Blue Ridge, whereas it is scattered throughout the baseline map (Fig. 3). Where forest types at the fine scale intermingle (New England, the Great Lakes, the Intermountain West and the Western mountains, Fig. 2), patterns of homogenous aggregation error closely resemble aggregation error of the baseline simulations.

Homogenizing air temperature produced a fine resolution aggregation error $\left(E h_{f}\right)$ with stronger regional biases than that of the baseline aggregation error $E_{B}$. More positive values of $E h_{f}$ occurred in the East and Northeast, with consistently higher values in New England, the Great Lakes region, and the interior Western mountains (Fig. 5b). These regions of positive aggregation error coincide with substantial variability in the annual average air temperature. Homogenizing air temperature resulted in lower monthly air temperature values, particularly for months at the beginning and the end of the growing season. In contrast, patterns of aggregation error for homogeneous precipitation (Fig. 5c) show no geographic bias and are within $10 \%$ of no aggregation error across the entire United States (Table 3).

According to the above analysis, much of the baseline aggregation error is produced by classification of forest type at the coarse resolution and homogenizing air temperature to the coarse resolution. Precipitation has only a slight effect on aggregation error under baseline conditions.

\subsection{Climate change response and aggregation error}

Net primary production for all forests increased under both climate change scenarios at both resolutions (Table 4). Under the OSU climate, NPP of all forests increased approximately $30 \%$ above the baseline NPP response whereas under the GFDL-Q climate NPP of all forests increased less than $13 \%$. Within each climate change scenario, the response to climate change at the coarse resolution differed by less than $1 \%$ from the response to climate change at the finer resolution.

By forest type, the NPP responses increased from 2.3 to $48.3 \%$, varying by forest type and climate scenario (Table 4). The NPP response for boreal and forested boreal wetland forests was 4 to $7 \%$ greater under the GFDL-Q climate than under the OSU climate. However, for mixed temperate, deciduous, and temperate forested wetland, the NPP increase under the OSU climate was 18 to $40 \%$ greater than under the GFDL-Q climate. The responses for temperate forested wetland under the OSU climate (30.9 to 57.8\%) were completely outside the range of temperate forested wetland responses for the GFDL-Q climate (-7.6 to $12.4 \%$ ). Within each climate scenario, forest NPP responses at the coarse resolution differed by less than $2 \%$ from the NPP response to climate change at the fine resolution for all forest types but conifer, which differed by less than $6 \%$.

Table 4. Net primary production (NPP) response to climate change for coarse and fine resolution input data. Responses are in percentages relative to baseline NPP (Eqs. 8-11). Means, standard deviations (in parentheses) and ranges for OSU and GFDL-Q climates are relative to baseline for the same resolution grid cells

\begin{tabular}{|c|c|c|c|c|c|}
\hline \multirow{3}{*}{$\begin{array}{l}\text { Forest type } \\
\text { Boreal }\end{array}$} & \multirow{3}{*}{$\begin{array}{l}\text { Grid } \\
\text { Fine } \\
\text { Coarse }\end{array}$} & \multicolumn{4}{|c|}{ Percent change in NPP } \\
\hline & & \multicolumn{2}{|c|}{ OSU $\left(\mathrm{d}_{\mathrm{OS} 10}, \mathrm{~d}_{\mathrm{OS50}}\right)$} & \multicolumn{2}{|c|}{ GFDL-Q $\left(\mathrm{d}_{\mathrm{GQ10}}, \mathrm{d}_{\mathrm{GQ} 50}\right)$} \\
\hline & & $\begin{array}{l}22.4(5.1) \\
23.8(13.4)\end{array}$ & $\begin{array}{l}19.5 \text { to } 35.8 \\
17.7 \text { to } 59.5\end{array}$ & $\begin{array}{l}30.2(12.8) \\
30.9(19.2)\end{array}$ & $\begin{array}{l}24.8 \text { to } 64.2 \\
23.1 \text { to } 82.1\end{array}$ \\
\hline Forested boreal wetland & $\begin{array}{l}\text { Fine } \\
\text { Coarse }\end{array}$ & $\begin{array}{l}19.6(0.5) \\
19.3(0.3)\end{array}$ & $\begin{array}{l}18.8 \text { to } 19.9 \\
18.9 \text { to } 19.5\end{array}$ & $\begin{array}{l}24.8(1.0) \\
23.5(1.9)\end{array}$ & $\begin{array}{l}23.7 \text { to } 25.9 \\
20.7 \text { to } 24.9\end{array}$ \\
\hline Mixed temperate & $\begin{array}{l}\text { Fine } \\
\text { Coarse }\end{array}$ & $\begin{array}{l}27.5(4.8) \\
27.4(5.2)\end{array}$ & $\begin{array}{r}2.0 \text { to } 45.2 \\
-0.3 \text { to } 46.1\end{array}$ & $\begin{array}{l}9.0(11.8) \\
9.3(12.2)\end{array}$ & $\begin{array}{l}-12.8 \text { to } 35.6 \\
-12.9 \text { to } 41.0\end{array}$ \\
\hline Conifers & $\begin{array}{l}\text { Fine } \\
\text { Coarse }\end{array}$ & $\begin{array}{l}32.4(8.1) \\
35.3(10.7)\end{array}$ & $\begin{array}{l}15.8 \text { to } 47.1 \\
18.3 \text { to } 53.4\end{array}$ & $\begin{array}{l}42.7(18.4) \\
48.3(20.4)\end{array}$ & $\begin{array}{l}0.9 \text { to } 81.5 \\
2.4 \text { to } 78.0\end{array}$ \\
\hline Deciduous & $\begin{array}{l}\text { Fine } \\
\text { Coarse }\end{array}$ & $\begin{array}{l}29.9(3.5) \\
29.9(3.7)\end{array}$ & $\begin{array}{l}17.8 \text { to } 52.2 \\
15.0 \text { to } 49.6\end{array}$ & $\begin{array}{l}7.7(7.1) \\
7.5(7.4)\end{array}$ & $\begin{array}{l}-13.9 \text { to } 28.4 \\
-16.7 \text { to } 29.3\end{array}$ \\
\hline Temperate forested wetland & $\begin{array}{l}\text { Fine } \\
\text { Coarse }\end{array}$ & $\begin{array}{l}41.4(6.8) \\
42.2(7.4)\end{array}$ & $\begin{array}{l}30.9 \text { to } 56.5 \\
32.1 \text { to } 57.8\end{array}$ & $\begin{array}{l}2.5(3.5) \\
2.3(3.7)\end{array}$ & $\begin{array}{l}-5.2 \text { to } 12.1 \\
-7.6 \text { to } 12.4\end{array}$ \\
\hline All forests & $\begin{array}{l}\text { Fine } \\
\text { Coarse }\end{array}$ & $\begin{array}{l}29.5(6.0) \\
29.6(7.1)\end{array}$ & $\begin{array}{r}2.0 \text { to } 56.5 \\
-0.3 \text { to } 59.5\end{array}$ & $\begin{array}{l}12.4(15.8) \\
13.1(17.5)\end{array}$ & $\begin{array}{l}-13.9 \text { to } 81.5 \\
-16.7 \text { to } 82.1\end{array}$ \\
\hline
\end{tabular}




\section{Forest Response to Climate Change Scenarios}
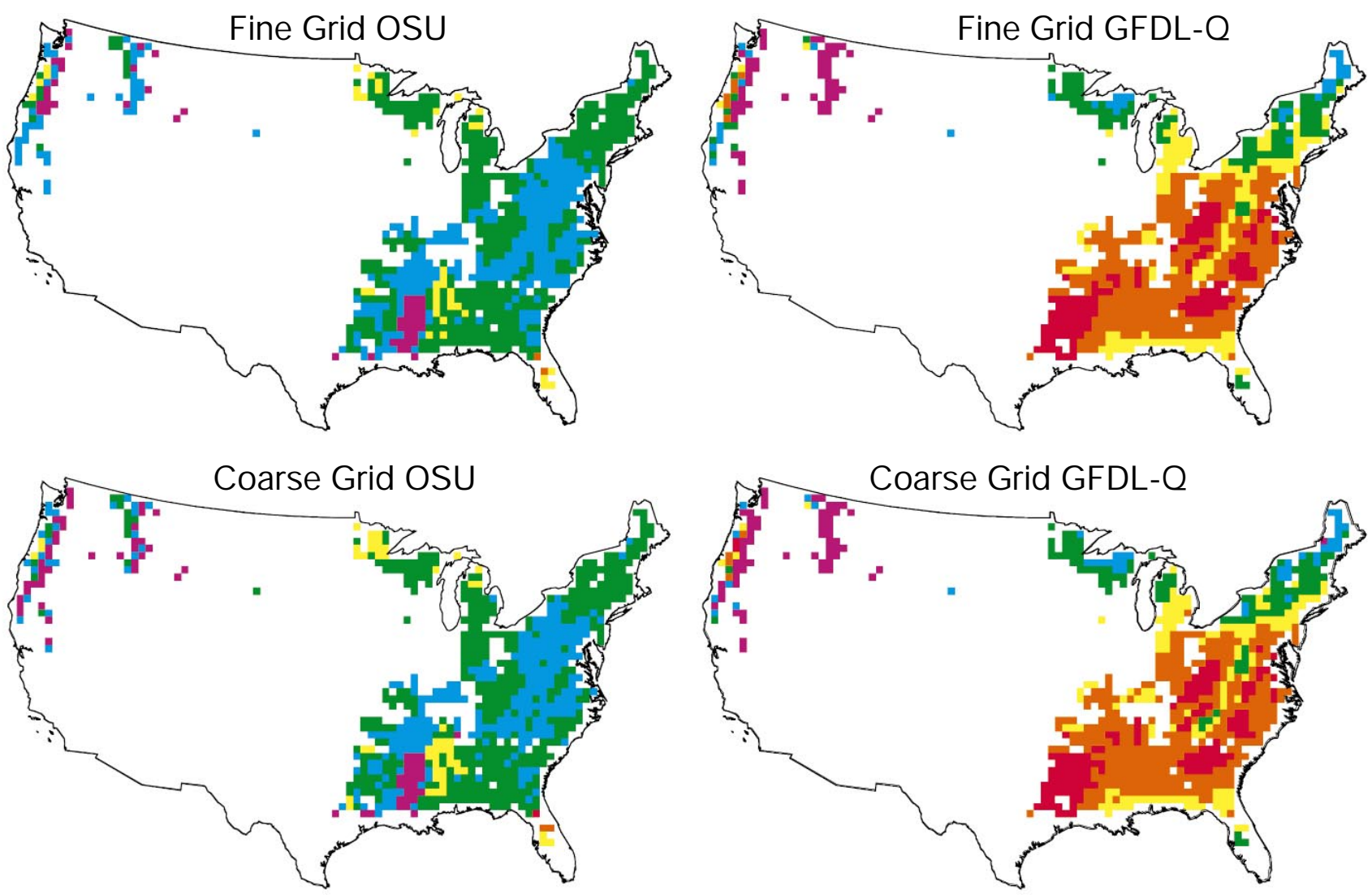

Total \% Difference

$\begin{array}{ll}\square-17.00 \text { to }-10.00 & \square 10.01 \text { to } 20.00 \\ \square-10.01 \text { to } 0.00 & \square 20.01 \text { to } 30.00 \\ \square 0.01 \text { to } 10.00 & \square 30.01 \text { to } 82.00\end{array}$

Fig. 6. Forest response to climate change scenarios: OSU and GFDL-Q fine and coarse resolution grid NPP $\left(\mathrm{d}_{\mathrm{OS} 10}, \mathrm{~d}_{\mathrm{OS5} 50}\right.$, $\mathrm{d}_{\mathrm{GQ} 10}$, and $\mathrm{d}_{\mathrm{GQ} 50}$; Eqs. 8-11)

Spatially, the pattern of NPP responses varied more across climate scenarios than across resolutions (Fig. 6). Although increases occurred under both climates in the West, the responses in the South and Mid-Atlantic forests were dramatically different across the 2 climate scenarios. For the GFDL-Q climate, the southern and mid-Atlantic forest NPP declined up to $17 \%$ relative to the baseline NPP, whereas under the OSU climate these forests increased in NPP from 10 to $82 \%$. The spatial pattern of the forest responses was similar across the coarse and fine resolutions within each climate scenario.

Aggregation error for the OSU climate was similar to the error for the GFDL-Q climate (Table 5) and both results were similar to the aggregation error of the baseline climate across all

Table 5. Aggregation error for climate change scenarios ( $E_{\mathrm{OS}}$ and $\mathrm{E}_{\mathrm{GQ}}$, Eqs. 12 $\& 13)$. Values represent means, with standard deviation in parentheses, and ranges of differences

\begin{tabular}{|c|c|c|c|c|}
\hline \multirow[t]{2}{*}{ Forest type } & \multicolumn{2}{|c|}{ OSU (E $\left.\mathrm{E}_{\mathrm{OS}}\right)$} & \multicolumn{2}{|c|}{ GFDL-Q $\left(E_{\mathrm{GQ}}\right)$} \\
\hline & Mean (SD) & Range & Mean (SD) & Range \\
\hline Boreal & $11.2(6.4)$ & 4.1 to 24.2 & $11.8(6.0)$ & 4.1 to 22.7 \\
\hline Forested boreal wetland & 9.8 (12.3) & -0.2 to 27.5 & 10.4 (12.9) & 0 to 29.1 \\
\hline M ixed temperate & $0.6(4.7)$ & -28.6 to 12.2 & $0(4.6)$ & -43.4 to 7.5 \\
\hline Conifers & $-3.7(6.0)$ & -25.2 to 9.8 & $-5.5(6.2)$ & -27.4 to 7.8 \\
\hline Deciduous & $-1.4(2.8)$ & -24.5 to 2.4 & $-1.2(2.7)$ & -25.1 to 2.6 \\
\hline Temperate forested wetland & $-1.5(2.8)$ & -11.2 to 2.2 & $-0.8(1.5)$ & -5.9 to 0.3 \\
\hline All forests & $-0.5(4.8)$ & -28.6 to 27.5 & $-0.8(4.8)$ & -43.4 to 29.1 \\
\hline
\end{tabular}



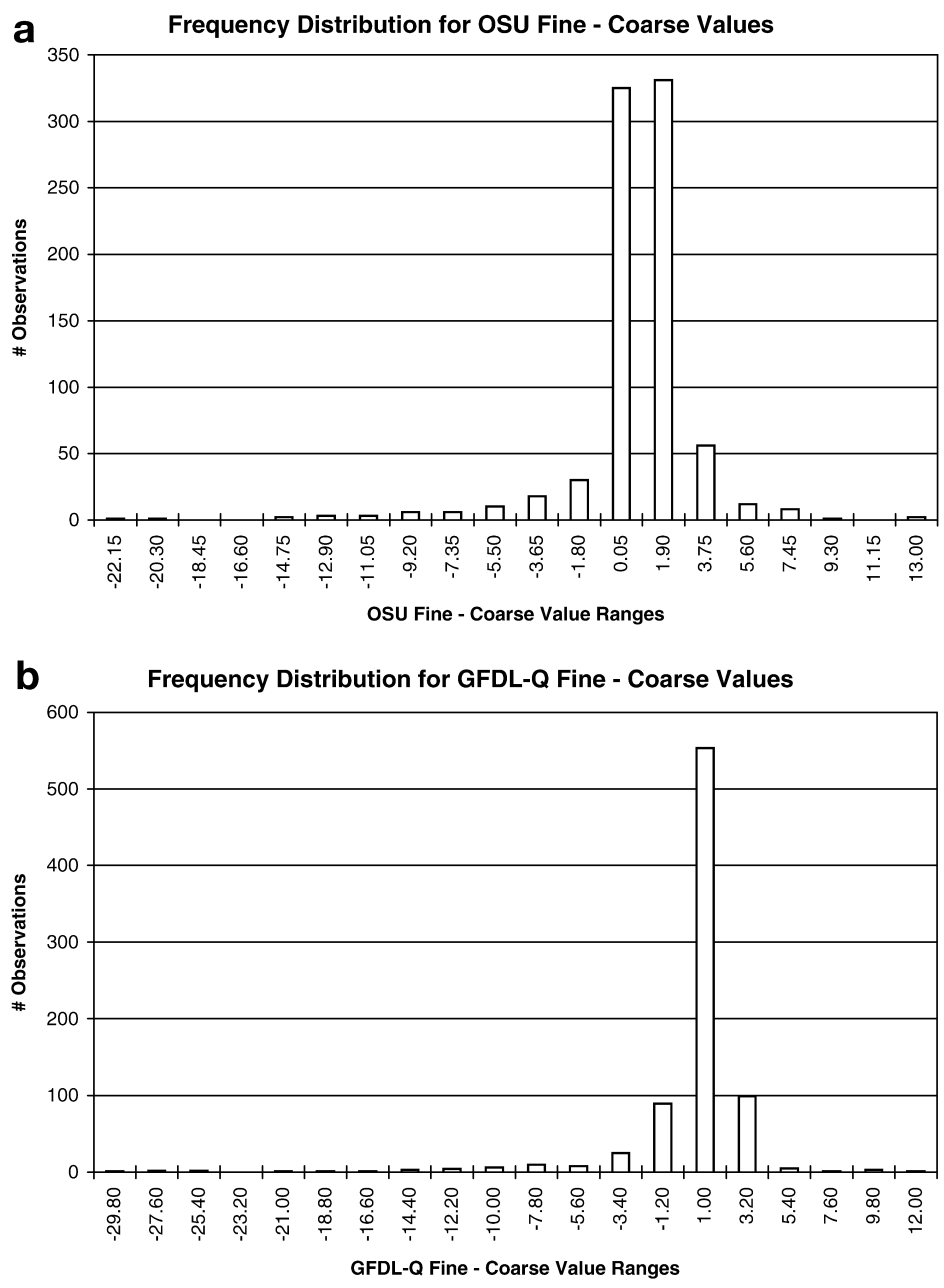

Fig. 7. Distribution of differences in forest response to climate change:

(a) $d_{O S 10}-d_{O S 50}$ and (b) $d_{G Q 10}-d_{G Q 50}$

mates (Fig. 6) are generally insensitive to inputs at the 2 different resolutions (Fig. 7). Most of the variation in differences between relative responses at the 2 resolutions is within $2 \%$ for the OSU climate and $1 \%$ for the GFDL-Q climate.

Aggregation error within forest types was similar in magnitude and sign across the baseline and the 2 climate scenarios. The highest error in all climate scenarios occurred in the boreal and forested boreal wetland forests ( 11.8 and $10.4 \%$ respectively) and the absolute value of the aggregation error for the other forests was less than $5.5 \%$. Only in the temperate conifer forests did aggregation error noticeably increase from baseline to the new climates, widening by approximately $-2 \%$ under OSU and $-4 \%$ for GFDL-Q. The GFDL-Q climate produced greater gridlevel aggregation error for some of the mixed temperate forest grids, with maximum differences of $-43.4 \%$ compared to $-28.6 \%$ for the OSU climate. Geographically, aggregation error for both OSU and GFDL-Q
(Fig. 8) was concentrated in the same areas as that of baseline climate (Fig. 3). The largest aggregation error occurred around the Great Lakes, in New England, and in the Rocky Mountains. The smallest aggregation error, less than $10 \%$, was found in the South and the Mid-Atlantic, an area that had the greatest differences in the NPP response to climate change, -17 to $82 \%$ (Fig. 6).

\section{DISCUSSION AND CONCLUSIONS}

Large-scale ecosystem models typically make estimates of carbon cycling at $0.5^{\circ} \mathrm{spa}$ tial resolution (Melillo et al. 1993, VEMAP Members 1995, Heimann et al. 1998, Cramer et al. 1999, Kicklighter et al. 1999); near the equator $0.5^{\circ}$ resolution is approximately $50 \mathrm{~km}$ resolution. This resolution was chosen because the data required as input to these models has traditionally been organized at $0.5^{\circ}$ (e.g. Legates \& Willmott 1990a, b, Leemans \& Cramer 1991, Kittel et al. 1995, VEMAP M embers 1995, Cramer et al. pers. comm.). Climate change scenarios for the large-scale ecosystem models are created by applying the responses of climate models to long-term climate data that has been organized at $0.5^{\circ}$ resolution (e.g. see M elillo et al. 1993, Kittel et al. 1995, VEMAP Members 1995).

Aggregation error is an issue for largescale ecosystem models because the responses of ecosystems to changes in inputs or driving variables are often non-linear (O'N eill 1979, Rastetter et al. 1992). Because ecosystem models are generally developed in the context of process-based studies that occur at resolutions between a meter and a hectare, aggregation error will likely occur when the models are applied to a larger area by using inputs that have been averaged over the larger area. There are a number of techniques that can be employed in ecosystem models to reduce aggregation error. One technique of scaling plot-level data to larger resolutions is transmutation (see O'N eill 1979), which involves the flattening of fine-scale processbased relationships with respect to driving variables. This technique was employed by Raich et al. (1991) in developing the first version of TEM, and is applicable to process-based relationships that tend to become asymptotic as the driving variables get larger, i.e. concave relationships (e.g. see Fig. 1 of Rastetter et al. 1992). In applying this technique to the calculation of processes that depend on driving variables, Raich et 

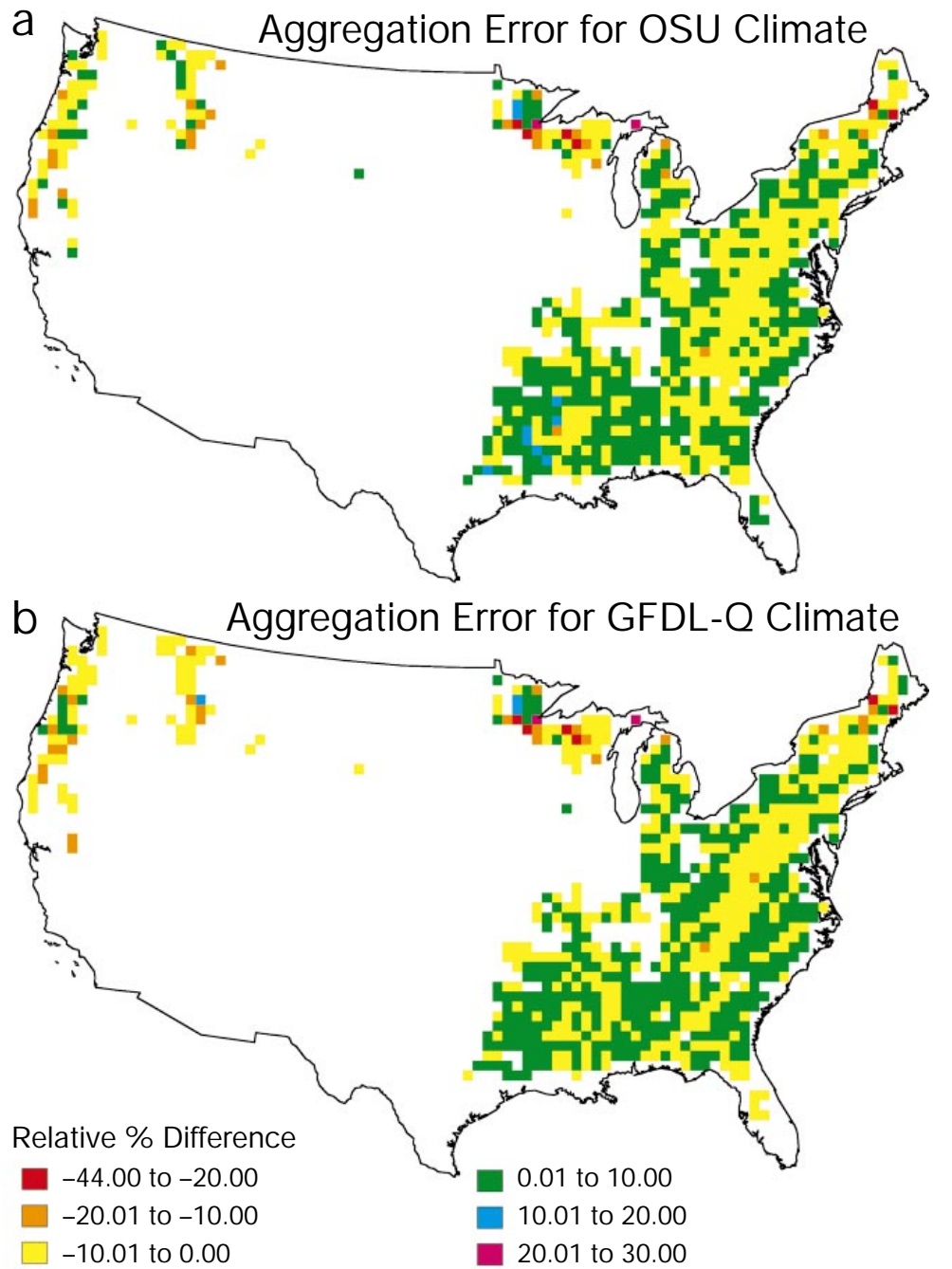

Fig. 8. Aggregation error for (a) OSU and (b) GFDL-Q climates, $E_{O S}$ and $\mathrm{E}_{\mathrm{GQ}}$ (Eqs. $\left.12 \& 13\right)$

al. (1991) assumed that the greater the point-to-point heterogeneity of the driving variable, the lower the range observed in the dependent process. This application of transmutation as a scaling technique decreases the sensitivity of relationships according to the expected heterogeneity of the dependent variable at coarse resolution (Raich et al. 1991).

In addition to transmutation, Rastetter et al. (1992) described 4 additional techniques to reduce aggregation error. These techniques include moment expansions, partial transformations, calibration, and partitioning. Moment expansions are derived from Taylor series expansion of the fine-scale function in the expectation operator; an infinite number of terms in the Taylor expansion will result in a corrected estimate that converges to the 'true' value. The disadvantage of this technique is that it is not clear how many terms are required before the series converges to a reason- able estimate of the aggregated relationship (Rastetter et al. 1992). This technique has not been employed in the development of TEM.

Partial transformation is a technique that uses an expectation operator to correct finescale relationships to make coarse-scale estimates when the probability density function of the driving variable is known, i.e. when the fine-scale statistical properties of driving variable are understood at the coarser resolution of model application. This technique was applied to improve the effects of sub-monthly precipitation events on the monthly estimates of soil moisture by the water balance model of Vorosmarty et al. (1989; see Vorosmarty \& Moore 1991). Thus, the technique of partial transformations has been employed in the TEM simulations to correct for temporal aggregation error in soil moisture estimates. Although this technique is powerful, it has not been used to correct for spatial aggregation error in TEM because the technique is tedious and requires that each process is corrected for all sources of variability (Rastetter et al. 1992).

The technique of calibration involves altering the parameters in a fine-scale relationship so that the altered relationship simulates the coarse resolution dependent variable when using the coarse resolution driving variables. In comparing the performance of different scaling techniques, Rastetter et al. (1992) found that application of the calibration technique was very effective at reducing aggregation error, particularly when combined with the partial transformation technique. In TEM, rate-limiting parameters of ecosystem processes have been calibrated to the fluxes and pools of intensively studied sites for each of the major vegetation types in the terrestrial biosphere in the context of the $0.5^{\circ}$ driving variables of the grid cell containing the site. This application of the calibration technique in TEM assumes that fluxes and pools of an intensively studied site are representative of the fluxes and pools of the $0.5^{\circ}$ grid cell. Although TEM has been calibrated to $0.5^{\circ}$ input data, it is not clear where the underlying resolution of the model lies on the continuum between stand-level and $0.5^{\circ}$ resolution. Some large-scale biogeochemical models have taken a biome-scale approach to calibration. For example, the flux equations of the Frankfurt Biosphere M odel (FBM , Kindermann et al. 1993, 1996, Lüdeke et al. 1994, Kohlmaier et al. 1997) contain free parameters that are 
calibrated until the NPP of a vegetation type equals average ecological estimates. The FBM and many other large-scale ecosystem models, including TEM, have conducted validation analyses by comparing $0.5^{\circ}$ estimates with stand-based estimates (e.g. see M elillo et al. 1993, Kohlmaier et al. 1997). Although FBM uses $0.5^{\circ}$ input data to make estimates for each grid cell within a vegetation type, it is not clear where the underlying resolution of the model lies on the continuum between stand-level and biome-level resolution. The lack of coarse resolution data for both model calibration and validation is the primary limitation of using calibration to reduce spatial aggregation error in large-scale models. Although models are calibrated to a particular resolution, without coarse resolution validation data there is no guarantee that models have effectively reduced aggregation error associated with sub-grid variability. Partitioning is a scaling technique that has the potential to reduce spatial aggregation error in calibrated models.

The technique of partitioning reduces spatial aggregation error by partitioning some of the driving variables into relatively homogeneous units within the coarse resolution spatial unit. The key to employing this technique is to identify the driving variables to be partitioned by ascertaining model sensitivity to the variability of driving variables within the coarse resolution spatial unit. This technique has been employed in TEM by having the model make separate calculations for vegetation types that are clearly mosaics at coarse resolution. For example, for each grid cell in temperate mixed forest TEM makes separate simulations based on parameters for temperate deciduous forest and temperate conifer forest. The estimates based on these simulations contribute equally to the estimated fluxes and pools of each grid cell. An extension of this partitioning strategy would be to weight simulations by the relative area occupied by each forest type within a grid cell. A related application of partitioning is to collect fine-scale heterogeneity in land cover from several coarse resolution grid cells that are in close proximity to each other into a single coarse resolution grid cell. This strategy, which conserves the area of each land cover type, assumes that the effect of climatic variability on aggregation error is minimal. A partitioning strategy could be applied to climatic variables in order to evaluate this assumption. In this study we evaluated whether a partitioning strategy applied to different driving variables has the potential to reduce spatial aggregation error in large-scale ecosystem models that are used to assess the impacts of climate change on the supply and demand of timber.

Although the responses of large-scale ecosystem models have been used to assess the potential impacts of climate change on the supply and demand of timber
( oyce et al. 1995, Perez-Garcia et al. 1997, Sohngren et al. 1998), there have been no studies that have examined how the resolution of input data influences the responses of the models over the spatial scope of impact assessments. The availability of input data with $10 \mathrm{~km}$ resolution for the spatial scope of the conterminous U.S. provided the opportunity for us to examine how both the baseline estimates and climate change responses of large-scale ecosystem models might be influenced by the resolution of the input data. The influence of the spatial resolution of input data on the baseline estimates and climate change responses depends on the scale of analysis. In this study we focused our analysis at 3 spatial scales: grid cell, forest type, and national.

The grid-cell resolution, which is $50 \mathrm{~km}$ in this study, is most relevant to stand-level forest managers. Although the grid-cell aggregation error of the baseline NPP estimates ranges up to approximately $25 \%$ in our simulations, most of the variation in aggregation error is within $9 \%$ ( 2 standard deviations). Because it is difficult to measure stand-level NPP within $20 \%$, this level of aggregation error is generally acceptable in the context of estimating NPP of a typical stand within a $50 \mathrm{~km}$ grid cell. Our analyses indicate that aggregation error is largest in transition regions and regions with substantial variability in temperature. In transition regions, aggregation error is primarily associated with the representation of a mosaic of forest types with a single forest type at $50 \mathrm{~km}$ resolution. This source of aggregation error can easily be minimized by making NPP estimates for each forest type within a $50 \mathrm{~km}$ grid cell and aggregating estimates based on the proportion of each forest type within the grid cell. This approach has been used by Bonan (1995) as a means of representing vegetative heterogeneity for estimating carbon, water, and energy exchange in the surface boundary layer of GCMs. In regions with substantial variability in temperature, the averaging of temperature across the $50 \mathrm{~km}$ grid cell also influences aggregation error of the baseline estimates by TEM . Pierce $\&$ Running (1995) found that averaging temperature substantially influenced aggregation error in regions with substantial temperature variability. It may be possible to achieve computational efficiency at $50 \mathrm{~km}$ resolution by aggregating temperature for a limited number of mean annual temperature bands, making NPP estimates for each band, and aggregating estimates based on the proportion of each temperature band within the grid cell.

Compared to the baseline estimates of NPP at the grid-cell resolution, the aggregation errors of the NPP estimates for the OSU and GFDL climates have similar means and standard deviations. The ranges of aggregation error are also similar, although the range of 
mixed temperate forest for the GFDL is larger in comparison to the OSU and baseline simulations. Thus, we conclude that aggregation error is relatively insensitive to potential climate changes. In integrated ecological-economic assessments of the forest sector responses to climate change, relative responses of NPP are communicated between ecological and economic models (e.g. see J oyce et al. 1995, Perez-Garcia et al. 1997). Because aggregation error of the absolute estimates is insensitive to different climates, the relative responses of NPP are generally insensitive to inputs at the 2 resolutions in this study. The differences in NPP responses at the 2 resolutions are small in comparison to NPP responses to different climate scenarios. Thus, differences in NPP responses at the 2 resolutions can be ignored in impact assessments that evaluate sensitivities to different climate change scenarios.

The resolution of forest types is most relevant to country-specific economic assessments of the impacts of climate change on timber resources. For example, relative climatic responses of NPP for different forest types in different regions were used as inputs for a national assessment (J oyce et al. 1995). Except for boreal and forested boreal wetland forests, the mean aggregation error of baseline NPP estimates is less than $2 \%$ for each forest type. In contrast, aggregation error for boreal and forested boreal wetland forests is approximately $10 \%$. This level of error is caused primarily by the over-representation of boreal and forested boreal wetland forests and under-representation of more highly productive forests in the $50 \mathrm{~km}$ simulation. In comparison to the baseline simulations, mean aggregation error for the absolute estimates of each forest type in the climate change simulations is similar except for temperate conifer forest $(-3.7 \%$ for OSU and $-5.5 \%$ for GFDL vs $-1.6 \%$ for baseline climate). Similar to aggregation error, the relative responses of NPP at each resolution are similar except for conifer forests (2.9 and 5.6\% lower response for the fine resolution OSU and GFDL simulations). The negative aggregation errors and lower responses for temperate conifer forests are associated with the substantial forest and temperature heterogeneity in the northern Rocky Mountains and in western Washington, Oregon, and California. Because differences between the responses of NPP at different resolutions are small compared with the responses to different climate scenarios, they can generally be ignored in impact assessments that evaluate sensitivities to different climate change scenarios.

The national resolution is most relevant to global economic assessments of the impacts of climate change on timber resources. For example, relative climatic responses of NPP of hardwoods and softwoods for different regions were used as inputs for a national assessment (Perez-Garcia et al. 1997). For the conterminous United States, aggregation error was $-0.4 \%$ in the baseline simulation, $-0.5 \%$ in the OSU simulation, and $-0.8 \%$ in the GFDL simulation. Responses of NPP were 0.1 and $0.7 \%$ lower for the fine resolution OSU and GFDL simulations. Because these differences are minuscule compared to the national NPP responses, they can be ignored in impact assessments that evaluate sensitivities to different climate change scenarios.

Our results indicate that NPP responses of TEM to projected climate change are insensitive to the resolution of inputs in this study, but that aggregation error of absolute NPP estimates is sensitive to the resolution of inputs for some situations. Except for transition regions and regions with substantial variability in temperature, our simulations indicate that the use of $0.5^{\circ}$ resolution provides an acceptable level of aggregation error at the 3 scales of analysis in this study. Although aggregation error is a concern for grid cells and forest types in these regions, NPP estimates at the national scale were not influenced by the different resolutions of inputs. Because aggregation error is generally less than measurement error, it is important to consider the computational costs associated with finer resolution estimates. In terms of computational cost, improving the homogeneity of grid cells may be preferable to simulations at a finer resolution. There are a number of techniques to improve the homogeneity of landscape units (e.g. Klemes 1983, Rastetter et al. 1992, M arceau et al. 1994, Kite 1995, Lathrop et al. 1995, Pierce \& Running 1995). At large spatial scales, we recommend using the partitioning technique discussed by Rastetter et al. (1992) to reduce aggregation errors associated with vegetation and temperature inputs. To reduce aggregation error in transition regions, we suggest making NPP estimates for each forest type within a $50 \mathrm{~km}$ grid cell and aggregating estimates based on the proportion of each forest type within the grid cell. To reduce aggregation error in regions with substantial variability in temperature, we suggest making NPP estimates for each forest type within different mean annual temperature bands within a $50 \mathrm{~km}$ grid cell and aggregating these estimates. These recommendations focus computational intensity in heterogeneous regions, and avoid computational intensity in regions that are relatively homogeneous.

It is important to recognize that our conclusions in this study are based on 2 resolutions and 1 biogeochemical model. Pierce \& Running (1995) used a different biogeochemical model to simulate NPP for various resolutions ranging from 1 to $110 \mathrm{~km}^{2}$ in a region of complex topography. At the coarsest scale, they found coarse resolution NPP was overestimated by up to $30 \%$ relative to NPP estimates based on estimates at the finest resolution. Although our results 
agree with those of Pierce \& Running (1995) in identifying a sensitivity of aggregation error of baseline estimates in regions with substantial variability in temperature, our results indicate that vegetation heterogeneity may be a more important source of aggregation error than temperature variability. Because most large-scale biogeochemical models can be calibrated to stand-level data using either stand-level or coarseresolution inputs, we believe a systematic analysis of aggregation error with several biogeochemical models across a range of spatial resolutions from stand to $0.5^{\circ}$ (e.g. $100 \mathrm{~m}^{2}$ to $1 \mathrm{~km}^{2}$ to $100 \mathrm{~km}^{2}$ to $2500 \mathrm{~km}^{2}$ ) should be undertaken in different forest regions to determine whether models agree on the relative roles of vegetation and climatic heterogeneity in aggregation error. Finally, it is important to verify our conclusion about the insensitivity of NPP responses to the resolution of inputs with other biogeochemical models. By clarifying the scaling issues associated with biogeochemical estimates and responses, these suggested studies would improve impact assessments that rely on the estimates of large-scale ecological models.

Acknowledgements. Our work was funded by the USDA Forest Service Resources Program and Assessment staff and the Northern Global Change Program. Maps were produced by Holly Lerner, Alicia Lizarraga, and Scott Powell. We thank Editor Robert Hamre and Biostatisticians Rudy King and J ill Williams for their helpful suggestions.

\section{LITERATURE CITED}

Bonan GB (1995) Land-atmosphere $\mathrm{CO}_{2}$ exchange simulated by a land surface process model coupled to an atmospheric general circulation model. J Geophys Res 100: 2817-2831

Costanza R, Maxwell T (1994) Resolution and predictability: an approach to the scaling problem. Landscape Ecol 9(1): 47-57

Cramer W, Kicklighter DW, Bondeau A, M oor B III, Churkina G, Nemry B, Ruimy A, Schloss A and participants of 'Potsdam '95' (1999) Comparing global models of terrestrial net primary productivity (NPP): overview of key results. Global Change Biol (in press)

Daly C, Neilson RP, Phillips DL (1994) A statistical-topographic model for mapping climatological precipitation over mountainous terrain. J Appl M eteorol 33:140-158

Hahn J, Warren SG, London J, Roy J L (1988) Climatological data for clouds over the globe from surface observation. US Dept of Energy, Oak Ridge, TN

Heimann M, Esser G, Hazeltine A, Kaduk J , Kicklighter DW, Knorr W, Kohlmaier GB, M cGuire AD, M elillo J, M oore B III, Otto RD, Prentice IC, Sauf W, Schloss A, Sitch S, Wittenberg U, Wurth G (1998) Evaluation of terrestrial carbon cycle models through simulations of the seasonal cycle of atmospheric $\mathrm{CO}_{2}$ : first results of a model intercomparison study. Global Biogeochem Cycles (in press)

Houghton JT, Meira Filho LG, Callander BA, Harris N, Kattenberg A, Maskell K (eds) (1996) Climate change 1995-the science of climate change. Contribution of Working Group I to the Second Assessment Report of the
Intergovernmental Panel on Climate Change. Cambridge University Press, Cambridge

J oyce LA (ed) (1995) Productivity of America's forests and climate change. General Technical Report RM-271. USDA Forest Service, Rocky M ountain Forest and Range Experiment Station, Fort Collins, $\mathrm{CO}$

J oyce LA, Mills J R, Heath LS, McGuire AD, Haynes RW, Birdsey RA (1995) Forest sector impacts from changes in forest productivity under climate change. J Biogeogr 22: 703-713

Kern J S (1994) Spatial patterns of soil organic carbon in the contiguous United States. Soil Sci Soc Am J 58:439-455

Kicklighter DW, Bondeau A, Schloss AL, Kaduk J, McGuire AD and participants of 'Potsdam '95' (1999) Comparing global models of terrestrial net primary productivity (NPP): global pattern and differentiation by major biomes. Global Change Biol (in press)

Kindermann J , Lüdeke MKB, Badeck FW, Otto RD, Klaudius A, Häger C, Würth G, Lang T, Dönges S, Habermehl S, Kohlmaier GH (1993) Structure of a global carbon exchange model for the terrestrial biosphere: the Frankfurt Biosphere Model (FBM). Water Air Soil Pollut 70:675-684

Kindermann J, Würth G, Kohlmaier GH, Badeck FW (1996) Interannual variation of carbon exchange fluxes in terrestrial ecosystems. Global Biogeochem Cycles 10:737-755

Kite GW (1995) Scaling of input data for macroscale hydrologic modeling. Water Resour Res 31(11):2769-2781

Kittel TGF, Ojima DS, Schimel DS, McKeown R, Bromberg J G, Painter TH, Rosenbloom NA, Parton WJ, Giorgi F (1996) Model-GIS integration and data set development for assessing the vulnerability of terrestrial ecosystems to climate change. In: Goodchild L, Steyaert B, Parks C, J ohnston C, Maidment D, Crane M, Glendinning S (eds) Proceedings Volume, Second International Conference on Integrating GIS and Environmental Modeling. GIS World Books, Fort Collins, CO, p 293-297

Klemes V (1983) Conceptualization and scale in hydrology. J Hydrol 65:1-23

Kohlmaier GH, Badeck FW, Otto RD, Häger C, Dönges S, Kindermann J, Würth $G$, Lang $T$, J äkel $U$, Nadler $A$, Ramge P, Klaudius A, Habermehl S, Lüdeke M KB (1997) The Frankfurt Biosphere M odel: a global process-oriented model for the seasonal and long-term $\mathrm{CO}_{2}$ exchange between terrestrial ecosystems and the atmosphere. II. Global results for potential vegetation in an assumed equilibrium state. Clim Res 8:61-87

Küchler AW (1975) Potential natural vegetation of the United States, 2nd edn. American Geographic Society, New York

Lathrop RG J r, Aber J D, Bognar J A (1995) Spatial variability of digital soil maps and its impact on regional ecosystem modeling. Ecol Model 82:1-10

Leemans R, Cramer WP (1991) The IIASA data base for mean monthly values of temperature, precipitation, and cloudiness on a global terrestrial grid. Int Inst Appl Syst Anal, Laxenburg

Legates DR, Willmott CJ (1990a) M ean seasonal and spatial variability in gauge-corrected global precipitation. Int J Climatol 10:111-127

Legates DR, Wilmott CJ (1990b) Mean seasonal and spatial variability in global surface air temperatures. Theor Appl Climatol 41:11-21

Lüdeke MKB, Badeck FW, Otto RD, Häger C, Dönges $S$, Kindermann J, Würth $G$, Lang $T$, J äkel $U$, Klaudius $A$, Ramge P, Habermehl S, Kohlmaier GH (1994) The Frankfurt Biosphere Model: a global process-oriented model for the seasonal and long-term $\mathrm{CO}_{2}$ exchange between terrestrial ecosystems and the atmosphere. I. Model descrip- 
tion and illustrative results for cold deciduous and boreal forests. Clim Res 4(2):143-166

Manabe S, Wetherald RT (1987) Large scale changes in soil wetness induced by an increase in carbon dioxide. J Atmos Sci 44:1211-1235

Marceau DJ , Howarth PJ , Gratton DJ (1994) Remote sensing and the measurement of geographical entities in a forested environment. 1. The scale and spatial aggregation problem. Remote Sens Environ 49:93-104

Marks D (1990) The sensitivity of potential evapotranspiration to climate change over the continental United States. In: Gocinski H, Marks D, Turner DP (eds) Biospheric feedbacks to climate change: the sensitivity of regional trace gas emissions, evapotranspiration, and energy balance to vegetation redistribution. EPA/600/3-90/078, USEPA, Corvallis, OR, p IV-1-IV-31

McGuire AD, Melillo J M, Kicklighter DW, J oyce LA (1995) Equilibrium responses of soil carbon to climate change: empirical and process-based estimates. J Biogeogr 22: 785-796

McGuire AD, Melillo J M, Kicklighter DW, Pan Y, Xiao X, Helfrich J , M oore B III, Vorosmarty CJ , Schloss AL (1997) Equilibrium responses of global net primary production and carbon storage to doubled atmospheric carbon dioxide: sensitivity to changes in vegetation nitrogen concentration. Global Biogeochem Cycles 11(2):173-189

Melillo J M, M cGuire AD, Kicklighter DW, M oore B III, Vorosmarty CJ, Schloss AL (1993) Global climate change and terrestrial net primary production. Nature 363:234-240

Melillo J M, Prentice IC, Farquar GD, Schultz ED, Sala OE (1996) Terrestrial biotic responses to environmental change and feedbacks to climate. In: Houghton J T, M eira Filho LG, Callander BA, Harris N, Kattenberg A, Maskell $\mathrm{K}$ (eds) Climate change 1995-the science of climate change: Contribution of Working Group I to the Second Assessment Report of the Intergovernmental Panel on Climate Change. Cambridge University Press, Cambridge, p 446-481

Neilson RP (1995) A model for predicting continental-scale vegetation distribution and water balance. Ecol Appl 5(2): 362-385

Neilson RP, Marks D (1994) A global perspective of regional vegetation and hydrologic sensitivities from climate change. J Veg Sci 5:715-730

O'Neill RV (1979) Transmutations across hierarchical levels. In: Innis GS, O'Neill RV (eds) Systems analysis of ecosystems. International Co-operative, Fairland, MD, p 59-78

Pan Y, McGuire AD, Kicklighter DW, Melillo J M (1996) The importance of climate and soils for estimates of net primary production: a sensitivity analysis with the terrestrial ecosystem model. Global Change Biol 2:5-23

Perez-Garcia J , J oyce LA, Binkley CS, McGuire AD (1997) Economic impacts of climatic change on the global forest

Editorial responsibility: Gerd Esser, Gießen, Germany sector an integrated ecological/economic assessment. Crit Rev Environ Sci Technol 27(Special):S123-S138

Pierce LL, Running SW (1995) The effects of aggregating subgrid land surface variation on large-scale estimates of net primary production. Landscape Ecol 10(4):239-253

Raich J W, Rastetter EB, M elillo J M, Kicklighter DW, Steudler PA, Peterson BJ , Grace AL, Moore B III, Vorosmarty CJ (1991) Potential net primary productivity in South America: application of a global model. Ecol Appl 1(4):399-429

Rastetter EB, King AW, Cosby BJ, Hornberger GM, O'N eill RV, Hobbie JE (1992) Aggregating fine-scale ecological knowledge to model coarser-scale attributes of ecosystems. Ecol Appl 2(1):55-70

Schlesinger ME, Zhao Z (1989) Seasonal climatic changes induced by doubled $\mathrm{CO}_{2}$ as simulated by the OSU atmospheric GCM/mixed-layer ocean model. J Clim 2:459-495

Sohngren B, Mendelsohn R, Neilson R (1998) Predicting $\mathrm{CO}_{2}$ emissions from forests during climatic change: a comparison of natural and human response models. A mbio 27(7): 509-513

Turner MG, O'Neill RV, Gardner RH, Milne BT (1989a) Effects of changing spatial scale on the analysis of landscape pattern. Landscape Ecol 3(3/4):153-162

Turner MG, Dale VH, Gardner RH (1989b) Predicting across scales: theory development and testing. Landscape Ecol 3(3/4):245-252

VEMAP Members (1995) Vegetation/ecosystem modeling and analysis project: comparing biogeography and biogeochemistry models in a continental-scale study of terrestrial ecosystem responses to climate change and $\mathrm{CO}_{2}$ doubling. Global Biogeochem Cycles 9(4):407-437

Vorosmarty CJ, Moore B III (1991) Modeling basin-scale hydrology in support of physical climate and global biogeochemical studies: an example using the Zambezi River. Surv Geophys 12:271-311

Vorosmarty CJ , Moore B III, Grace AL, Gildea MP, Melillo J M, Peterson BJ, Rastetter EB, Steudler PA (1989) Continental scale models of water balance and fluvial transport: an application to South America. Global Biogeochem Cycles 3(3):241-265

Watson RT, Zinyowera MC, Moss RH (eds) (1996) Climate change 1995, impacts, adaptations and mitigation of climate change: scientific-technical analyses. Contribution of Working Group II to the Second Assessment Report of the Intergovernmental Panel on Climate Change. Cambridge University Press, Cambridge

Woodward FI, Smith TM, Emanuel WR (1995) A global land primary productivity and phytogeography model. Global Biogeochem Cycles 9(4):471-490

Xiao X, Kicklighter DW, M elillo J M, M cGuire AD, Stone PH, Sokolov AP (1997) Linking a global terrestrial biogeochemical model with a 2-dimensional climate model: implications for the global carbon budget. Tellus 49b:18-37

Submitted: March 11, 1998; Accepted: November 14, 1998 Proofs received from author(s): J anuary 25, 1999 